\title{
Effects of tillage and crop rotation on yield and quality parameters of durum wheat in Tunisia
}

\author{
Nadia Chaieb ${ }^{a 1} *$, Mohsen Rezgui ${ }^{a}$, Sourour Ayed ${ }^{\mathrm{b}}$, Haithem Bahria ${ }^{\mathrm{a}}$, Hatem Cheikh \\ M'hamed $^{\text {a }}$, Mounir Rezgui ${ }^{a}$, Mohamed Annabi ${ }^{a}$ \\ a University of Carthage, Laboratory of Agronomy, National Institute for Agronomic Research in Tunisia, Hedi Karray street, \\ 2049 Ariana, Tunisia. \\ ${ }^{b}$ University of Carthage, Laboratory of Field Crop, National Institute for Agronomic Research in Tunisia, Hedi Karray street, \\ 2049 Ariana, Tunisia. \\ 1 On transfer from Regional Office of Agriculture Development Research Semi-Arid North West, B.P. 221-7100 Le Kef, \\ Tunisia to Regional Research Centre on Horticulture and Organic Agriculture (CRRHAB), University of Sousse, Chott \\ Mariem 4042, Tunisia. \\ * Corresponding author: Nadia CHAIEB E-mail address: chaiebnadiat@gmail.com
}

Keywords: Tillage system, crop-rotation system, durum wheat, yield, quality parameters

Publication date 31/05/2020, http://m.elewa.org/Journals/about-japs/

$1 \quad$ ABSTRACT

Conservation agriculture has been proposed as an alternative to conventional agriculture to mitigate the climate change impact and ensure food security. This study examined the effect of three tillage systems, ((conventional tillage (CT), chisel tillage (ChT) and no tillage (NT)) and two crop-rotation systems ((two year crop rotation (2-yr) and three year crop rotation (3-yr)) on some yield and quality parameters of two winter durum wheat genotypes. The results showed that biological yield (BY) and thousand kernel weight (TKW) were neither significantly affected by tillage, crop rotation nor genotype. Only the genotype significantly affected grain yield (GY). Grain protein content (GPC \%) showed higher values than straw protein content (SPC \%) and NT negatively affected GPC\%. Some significant differences of mineral elements were observed according to tillage system applied and NT showed the lowest values of grain $\mathrm{N}$, straw $\mathrm{K}$, straw $\mathrm{Ca}$ and straw $\mathrm{Na}$. Tillage system, croprotation system and genotype had no effect on total phenolic content (TPC) and total flavonoid content (TFC). Highly significant negative correlation $\left(-0,378^{* *}\right)$ was recorded between GY and grain N, and accordingly GPC\%. The two winter durum wheat genotypes demonstrated that with the two crop-rotation systems, yields and most of quality parameters under NT and ChT were similar to those under CT. This study expands our knowledge on durum wheat chemistry variation in relation to agricultural system adopted and provides a basis for selecting the adequate crop-rotation system and genotype following the NT adoption in Tunisian semi-arid areas.

\section{INTRODUCTION}

Durum wheat (Triticum turgidum subsp. durum (Desf.) Husn.) is one of the main crops cultivated and consumed in the Mediterranean. Its wealth in energy, proteins, mineral elements and fibre makes it contributes to human diet as a main staple food. The aleurone layer of wheat grains contains the largest part of mineral elements (Buri et al., 2004). Nevertheless, the mineral elements concentration may be differentially affected by the environment factors. In fact, management practices such as tillage systems could affect nutrient concentration and distribution (Lavado et al., 2001). Since phytochemicals are a key factor in 
evaluating quality, efforts have been made to determine the content of polyphenols and flavonoid of durum wheat. The antioxidants content of cereal grain could vary according to the genotype, the environment and possibly genotype-environment interactions ( $\mathrm{Yu}$ et al., 2003; Beta et al., 2005). In Tunisia, winter durum wheat is grown on about $50 \%$ of cereal area and accounts for $60 \%$ of cereals production (ONAGRI, 2015). Production is concentrated in northern Tunisia and satisfies $30 \%$ of country demand. However, the sustainability of production is threatened due to climate changes, unstable socio-economic conditions and problems of cultivar adaptation to agro-ecological zones. In semi-arid areas, soils are prone to erosion. Such conditions are aggravated by inappropriate agricultural practices. In fact, farmers are accustomed to till their soils more than twice a year before cereal sowing. In conventional tillage (CT), these tillage operations are necessary for weed control, seedbed preparation and to prevent crust formation. Accordingly, CT coupled with monoculture and overgrazing result loss of soil moisture, destruction of soil physical properties, and reduction of soil organic matter (Ben-Hammouda et al., 2005). In such situations, conservation agriculture has potential as an alternative to conventional agriculture. Conservation agriculture permits soil and water conservation and improvement of soil biological processes (Ben-Hammouda et al., 2005). In Tunisia, conservation agriculture

\section{METHODOLOGY}

3.1 Trials description: This study was conducted at the experimental station of the National Institute of Agricultural Research of Tunisia at Kef situated in north western Tunisia $\left(36^{\circ} 12^{\prime} \mathrm{N}, 8^{\circ} 42^{\prime} \mathrm{E}\right.$, elevation of $\left.518 \mathrm{~m}\right)$. The climate is semi-arid with an average of annual precipitation of about $450 \mathrm{~mm}$. The annual mean maximum and minimum temperatures and the rainfall of the experimental site are shown in Fig. 1. The soil was a silty clay $(50 \%$ of clay, $30 \%$ of silt and $20 \%$ of sand), with a $\mathrm{pH}$ of 7.5 . The trial was established during the based on NT was introduced in 1999 under rainfed conditions (Ben-Hammouda et al., 2005). Recently, Bahri et al. (2019) mapped 260 000 ha of agricultural area in two Tunisian contrasting climatic locations (semiarid and sub-humid) as priority for conservation agriculture adoption. Since the worldwide adoption of conservation agriculture, several studies have reported its effect on crop yield, soil physical properties, soil moisture and organic matter (Alvarez and Steinbach, 2009). The effects on grain yield have ranged from an increase, a decrease or no change (Hao et al., 2001). This effect depends on weather conditions and crop sequence used, rainfall during crop establishment and on the interaction between many others parameters (Brennan et al., 2014; Ercoli et al., 2017). Furthermore, no tillage is recognized to improve soil physico-chemical properties, soil moisture, soil organic matter and biological processes (Ben-Hammouda et al., 2005; Alvarez and Steinbach, 2009). In contrast, few research activities have been conducted on the tillage effects on grain quality. This is despite the fact that tillage can influence hormone activity (Liu et al., 2013), sucrose content (Hao et al., 2001), protein and gluten content (Šíp et al., 2013). The main objective of this study was to determine the effect of tillage and crop rotation systems on some yield and quality parameters of two Tunisian durum wheat genotypes in semi-arid conditions.

2010-2011 growing season, the sowing date was November 15 ${ }^{\text {th }}, 2014$ and the sampling was performed at the harvest July $10^{\text {th }}, 2015$. The experimental design was a split-split plot. The elementary plot was $120 \mathrm{~m}^{2}$ size $(20 \mathrm{~m} \times 6 \mathrm{~m})$. Two crop-rotation systems (biannual/2-yr and triennial/3-yr) combined three tillage systems: conventional tillage $(\mathrm{CT})$, chisel tillage $(\mathrm{ChT})$ and no tillage (NT) were tested. CT consisted of reversible moldboard ploughing to $30-40 \mathrm{~cm}$ depth followed by secondary tillage with offset $15-20 \mathrm{~cm}$ for seedbed preparation, for ChT 
chisel was used to 40-50 $\mathrm{cm}$ depth followed by cultivator $10-15 \mathrm{~cm}$ depth and NT plots were seeded by a direct driller. For NT, weeds were controlled with glyphosate at a rate of 3 L.ha ${ }^{-1}$. Two winter durum wheat genotypes, 'Maali' a modern genotype and 'Chili' an old genotype, were tested. The biannual crop rotation was faba bean (Vicia faba L. minor) and durum wheat, and the triennial crop-rotation was faba bean, durum wheat and barley (Hordeum vulgare
L.). The seeding rates were $160 \mathrm{~kg} \cdot \mathrm{ha}^{-1}$ for durum wheat, $130 \mathrm{~kg} \cdot \mathrm{ha}^{-1}$ for barley and 120 $\mathrm{kg} / \mathrm{ha}$ for faba bean. Fertilizers were surface broadcasted, durum wheat and barley received 100 kg.ha- ${ }^{-1}$ of Di-Ammonium Phosphate at sowing and $300 \mathrm{~kg} \cdot \mathrm{ha}^{-1}$ of ammonium nitrate half at early tillering and half at stem elongation stages. Faba bean received at sowing 33 kg.ha ${ }^{-1}$ of ammonium nitrate.

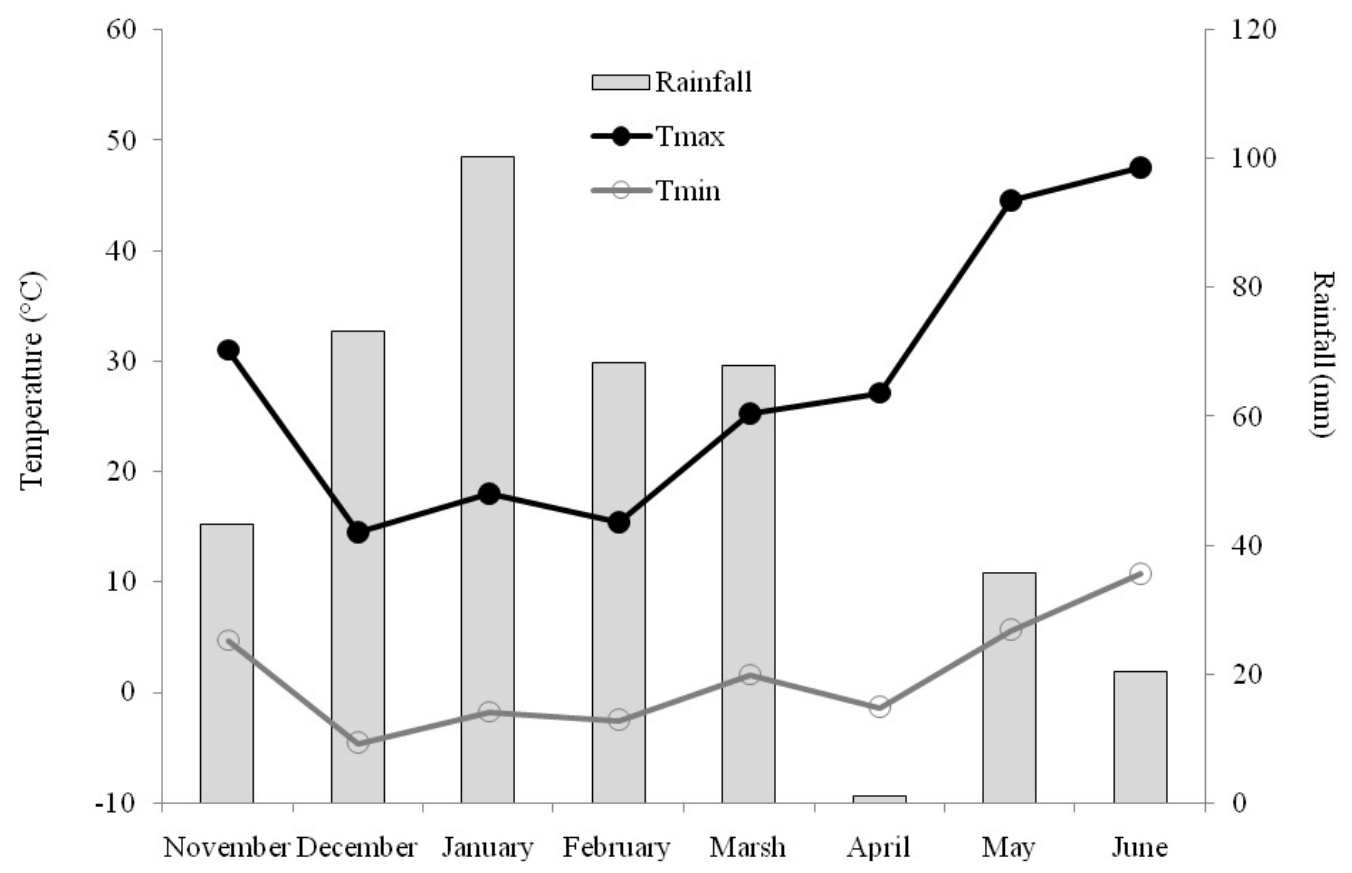

Figure 1: Minimum and maximum temperatures $\left({ }^{\circ} \mathrm{C}\right)$ and rainfall $(\mathrm{mm})$ recorded in Kef from November to June during the 2014-2015 growing season.

\subsection{Sampling and measurements: At} durum wheat maturity, yield parameters (biomass yield or biological yield (BY), grain yield (GY), and thousand-kernel weight $(\mathrm{TKW})$ ) were determined in quadruplicate. Then samples of grain and straw were ground, sieved and then stored until analysed. These samples were used to determine mineral elements, total phenolic content and total flavonoid content.

\subsection{Mineral elements and total protein} content determination: For mineral elements, about $1 \mathrm{~g}$ of dry sample were ashed in a muffle furnace at $600{ }^{\circ} \mathrm{C}$ for $6 \mathrm{~h}$, and mineralized with $\mathrm{HCl}$. Mineral elements measurements were made in quadruplicate. Potassium, calcium and sodium were estimated by flame photometry. Phosphorus concentrations were determined by spectrophotometry (Murphy and Riley, 1962). Kjeldahl method was used to determinate $\mathrm{N}$ (Kjeldahl, 1883) then protein content after multiplying Kjeldahl nitrogen by 5.7(De Vita et al., 2007) and expressed on a dry weight basis $(\%)$.

\subsection{Biochemical analysis}

3.4.1 Extraction:Samples of the ground plant material $(0.5 \mathrm{~g})$ were shaken with $25 \mathrm{ml}$ of 
methanol (80\%) for $2 \mathrm{~h}$ and filtrated through a Whatman filter paper to discard the solid phase. The extracts were prepared in quadruplicate and then stored until TPC and TFC analysis.

3.4.2 Determination of total phenolic content (TPC): The TPC of the two durum wheat genotypes were quantified using the Folin-Ciocalteu reagent according to Singleton and Rossi (1965). The absorbance of the reaction mixtures was measured at $720 \mathrm{~nm}$ against a blank after $1 \mathrm{~h}$. Gallic acid (GA) was used to obtain the standard curve $(0-1000$ ppm) and TPC was expressed as milligram of gallic acid equivalent (GAE) per gram of dry weight.

\subsubsection{Estimation of total flavonoid content} (TFC): For the TFC the colorimetric assay

\section{$4 \quad$ RESULTS}

4.1 Yield parameters: ANOVA results of durum wheat yield parameters are recorded in Table 1. Effects of tillage (T), crop rotation (R), and genotype $(G)$ were not significant on BY and TKW. However, genotype significantly reported by Zhishen et al. (1999) with minor modification (Chaieb et al., 2011) was used. Absorbance of the mixture was measured at $510 \mathrm{~nm}$ with methanol $80 \%$ used as the blank. Rutin was used to run the calibration curve and the flavonoid content was expressed as milligram of rutin equivalents (RE) per gram of dry weight.

3.5 Statistical Analysis: The Statistical Package for the Social Sciences software (SPSS 20.0, SPSS Inc., Chicago, IL, USA) was used for all statistical analysis to identify treatment effects and interactions (Two-way MANOVA and PEARSON correlation). If significant effects were found $(\mathrm{p}<0.05)$, differences between variables were checked by DUNCAN post hoc test.

affected the grain yield (GY) and straw yield (SY). "Maali" had higher GY and lower SY than "Chili". No significant effects of the interactions $(T \times R, T \times G, R \times G$, and $T \times R$ $\times G$ ) on yield parameters were noted.

Table 1: Effect of tillage, crop rotation and genotype on yield parameters of two durum wheat genotypes in Kef during 2014-2015 growing season.

\begin{tabular}{|c|c|c|c|}
\hline Treatment & $\mathrm{BY}^{*}\left(\mathrm{t} \mathrm{ha}^{-1}\right)$ & GY $\left(\mathrm{t} \mathrm{ha}^{-1}\right)$ & TKW (g) \\
\hline \multicolumn{4}{|l|}{ Tillage } \\
\hline CT & $10,2381 \pm 1,5359 a^{1}$ & $2,5746 \pm 0,7562 \mathrm{a}$ & $36,846 \pm 4,859 \mathrm{a}$ \\
\hline ChT & $11,3225 \pm 2,1585 \mathrm{a}$ & $2,9348 \pm 0,9156 \mathrm{a}$ & $36,532 \pm 5,083 \mathrm{a}$ \\
\hline NT & $11,2894 \pm 1,4567 \mathrm{a}$ & $2,6962 \pm 0,9574 \mathrm{a}$ & $34,829 \pm 4,838 \mathrm{a}$ \\
\hline \multicolumn{4}{|l|}{ Crop-rotation } \\
\hline $2-y r$ & $11,4004 \pm 1,9559 \mathrm{a}$ & $2,8749 \pm 0,9663 \mathrm{a}$ & $36,877 \pm 4,397 \mathrm{a}$ \\
\hline $3-y r$ & $10,4996 \pm 1,4971 \mathrm{a}$ & $2,5955 \pm 0,7679 \mathrm{a}$ & $35,261 \pm 5,334 \mathrm{a}$ \\
\hline \multicolumn{4}{|l|}{ Genotype } \\
\hline Chili & $11,0246 \pm 1,7327 \mathrm{a}$ & $2,0752 \pm 0,4011 \mathrm{~b}$ & $35,291 \pm 4,691 \mathrm{a}$ \\
\hline Maali & $10,8754 \pm 1,8645 \mathrm{a}$ & $3,3951 \pm 0,7032 \mathrm{a}$ & $36,847 \pm 5,088 \mathrm{a}$ \\
\hline
\end{tabular}

4.2 Mineral elements concentration: The concentrations of nitrogen, phosphorus and potassium of durum wheat grains and straw are presented in Table 2. Analysis of variance showed that the tillage $(\mathrm{T})$ had significant effect on grain $\mathrm{N}(\mathrm{GN})$ and straw $\mathrm{K} \quad(\mathrm{SK})$ concentrations. In fact, no tillage (NT) had the lowest $\mathrm{GN}$ and straw $\mathrm{K}(\mathrm{SK})$ concentrations. Only GK was significantly affected by crop rotation with the $3-\mathrm{yr}$ rotation showing the 
highest GK. In addition, genotype revealed no significant effect on $\mathrm{N}, \mathrm{P}$, and $\mathrm{K}$ concentrations, except for the SK. $T \times R$ interaction significantly affected the SK. It must be also noted that straw presented significant variability for $\mathrm{Ca}$ and $\mathrm{Na}$ content and 'Maali' showed higher SCa and lower SNa than "Chili". Analysis of variance of grain $\mathrm{Ca}$ (GCa) and grain $\mathrm{Na}(\mathrm{GNa})$ showed no significant effect of $T$ and $G . R \times G$ interaction had a significant effect on GCa. Tillage had significant effect on straw $\mathrm{Ca}(\mathrm{SCa})$ and straw $\mathrm{Na}(\mathrm{SNa})$ with $\mathrm{NT}$ having the lowest contents.

4.3 Protein content (\%): Protein content of durum wheat is a quality parameter to take into consideration for industrial processing. In general, grain showed significantly higher protein content than straw (Table 3). Only tillage ( $\mathrm{T}$ ) had significant effect on protein content, as NT showed significantly the lowest value for grain protein content was noted. 
Table 2: Effect of tillage, crop-rotation and genotype on nitrogen $(\mathrm{N})$, phosphorus $(\mathrm{P})$, potassium $(\mathrm{K})$, calcium (Ca) and sodium (Na) concentrations of two durum wheat genotypes grains and straw in Kef during 2014-2015 growing season.

\begin{tabular}{|c|c|c|c|c|c|c|c|c|c|c|}
\hline \multirow[t]{2}{*}{ Treatment } & \multicolumn{2}{|c|}{$\mathrm{N}\left(\mathrm{g} \mathrm{kg}^{-1}\right)$} & \multicolumn{2}{|c|}{$\mathrm{P}\left(\mathrm{g} \mathrm{kg}^{-1}\right)$} & \multicolumn{2}{|c|}{$\mathrm{K}\left(\mathrm{g} \mathrm{kg}^{-1}\right)$} & \multicolumn{2}{|c|}{$\mathrm{Ca}\left(\mathrm{g} \mathrm{kg}^{-1}\right)$} & \multicolumn{2}{|c|}{$\mathrm{Na}\left(\mathrm{g} \mathrm{kg}^{-1}\right)$} \\
\hline & $\mathrm{GN}^{*}$ & $\mathrm{SN}$ & GP & $\mathrm{SP}$ & GK & SK & $\mathrm{GCa}$ & $\mathrm{SCa}$ & $\mathrm{GNa}$ & $\mathrm{SNa}$ \\
\hline \multicolumn{11}{|l|}{ Tillage } \\
\hline CT & $\begin{array}{c}29,54 \pm 2,77 \\
a^{1} A^{2}\end{array}$ & $\begin{array}{c}5,88 \pm 1,02 \\
\text { a B }\end{array}$ & $\begin{array}{c}21,19 \pm 6,63 \\
\text { a } A_{1}\end{array}$ & $\begin{array}{c}2,30 \pm 0,64 \\
\mathrm{a} \mathrm{B}_{1}\end{array}$ & $\begin{array}{c}7,70 \pm 0,66 \\
\mathrm{a} \mathrm{B}_{2}\end{array}$ & $\begin{array}{c}12,99 \pm 1,89 \\
\mathrm{~b} \mathrm{~A}_{2}\end{array}$ & $\begin{array}{c}0,13 \pm 0,02 \\
\mathrm{a} \mathrm{B}_{3}\end{array}$ & $\begin{array}{c}1,59 \pm 0,46 \\
\mathrm{a} \mathrm{A}_{3}\end{array}$ & $\begin{array}{c}0,21 \pm 0,12 \\
\mathrm{a} \mathrm{B}_{4}\end{array}$ & $\begin{array}{c}2,21 \pm 0,80 \\
\mathrm{a} \mathrm{A}_{4}\end{array}$ \\
\hline ChT & $\begin{array}{c}28,57 \pm 3,47 \\
\text { a A }\end{array}$ & $\begin{array}{c}5,63 \pm 0,75 \\
\text { a B }\end{array}$ & $\begin{array}{c}22,75 \pm 4,58 \\
\text { a } A_{1}\end{array}$ & $\begin{array}{c}2,67 \pm 0,84 \\
\mathrm{a} \mathrm{B}_{1}\end{array}$ & $\begin{array}{c}7,53 \pm 0,58 \\
\text { a }_{2}\end{array}$ & $\begin{array}{c}14,25 \pm 2,34 \\
\text { a } A_{2}\end{array}$ & $\begin{array}{c}0,13 \pm 0,02 \\
\mathrm{a} \mathrm{B}_{3}\end{array}$ & $\begin{array}{c}1,60 \pm 0,39 \\
\mathrm{a} \mathrm{A}_{3}\end{array}$ & $\begin{array}{c}0,18 \pm 0,12 \\
\mathrm{a} \mathrm{B}_{4}\end{array}$ & $\begin{array}{c}1,66 \pm 0,34 \\
\mathrm{~b} \mathrm{~A}_{4}\end{array}$ \\
\hline NT & $\begin{array}{c}26,83 \pm 3,80 \\
\text { b A }\end{array}$ & $\begin{array}{c}5,40 \pm 1,40 \\
\text { a B }\end{array}$ & $\begin{array}{c}23,05 \pm 5,81 \\
\text { a } A_{1}\end{array}$ & $\begin{array}{c}2,03 \pm 0,82 \\
\mathrm{a} \mathrm{B}_{1}\end{array}$ & $\begin{array}{c}7,59 \pm 0,87 \\
\mathrm{a} \mathrm{B}_{2}\end{array}$ & $\begin{array}{c}12,57 \pm 2,26 \\
\text { b } A_{2}\end{array}$ & $\begin{array}{c}0,13 \pm 0,03 \\
\mathrm{a} \mathrm{B}_{3}\end{array}$ & $\begin{array}{c}1,35 \pm 0,48 \\
\mathrm{~b} \mathrm{~A}_{3}\end{array}$ & $\begin{array}{c}0,21 \pm 0,18 \\
\mathrm{a} \mathrm{B}_{4}\end{array}$ & $\begin{array}{c}1,55 \pm 0,68 \\
\mathrm{~b} \mathrm{~A}_{4}\end{array}$ \\
\hline \multicolumn{11}{|l|}{$\begin{array}{l}\text { Crop- } \\
\text { rotation }\end{array}$} \\
\hline $2-y r$ & $\begin{array}{c}27,44 \pm 3,93 \\
\text { a A }\end{array}$ & $\begin{array}{c}5,44 \pm 0,97 \\
\text { a B }\end{array}$ & $\begin{array}{c}21,41 \pm 6,24 \\
\text { a } A_{1}\end{array}$ & $\begin{array}{c}2,46 \pm 0,82 \\
\mathrm{a} \mathrm{B}_{1}\end{array}$ & $\begin{array}{c}7,33 \pm 0,65 \\
\mathrm{~b} \mathrm{~B}_{2}\end{array}$ & $\begin{array}{c}13,32 \pm 2,31 \\
\mathrm{a} \mathrm{A}_{2}\end{array}$ & $\begin{array}{c}0,13 \pm 0,03 \\
\mathrm{a} \mathrm{B}_{3}\end{array}$ & $\begin{array}{c}1,52 \pm 0,39 \\
\mathrm{a}_{3}\end{array}$ & $\begin{array}{c}0,20 \pm 0,15 \\
\mathrm{a} \mathrm{B}_{4}\end{array}$ & $\begin{array}{c}1,81 \pm 0,76 \\
\mathrm{a} \mathrm{A}_{4}\end{array}$ \\
\hline $3-y r$ & $\begin{array}{c}29,19 \pm 2,79 \\
\text { a A }\end{array}$ & $\begin{array}{c}5,82 \pm 1,23 \\
\text { a B }\end{array}$ & $\begin{array}{c}23,19 \pm 5,10 \\
\text { a } A_{1}\end{array}$ & $\begin{array}{c}2,22 \pm 0,77 \\
\mathrm{a} \mathrm{B}_{1}\end{array}$ & $\begin{array}{c}7,88 \pm 0,65 \\
\mathrm{a} \mathrm{B}_{2}\end{array}$ & $\begin{array}{c}13,24 \pm 2,21 \\
\mathrm{a} \mathrm{A}_{2}\end{array}$ & $\begin{array}{c}0,13 \pm 0,02 \\
\mathrm{a} \mathrm{B}_{3}\end{array}$ & $\begin{array}{c}1,51 \pm 0,51 \\
\mathrm{a} \mathrm{A}_{3}\end{array}$ & $\begin{array}{c}0,20 \pm 0,13 \\
\mathrm{a} \mathrm{B}_{4}\end{array}$ & $\begin{array}{c}1,81 \pm 0,62 \\
\mathrm{a} \mathrm{A}_{4}\end{array}$ \\
\hline \multicolumn{11}{|l|}{ Genotype } \\
\hline Chili & $\begin{array}{c}29,25 \pm 3,37 \\
\text { a A }\end{array}$ & $\begin{array}{c}5,77 \pm 0,93 \\
\text { a B }\end{array}$ & $\begin{array}{c}23,11 \pm 5,48 \\
\text { a } A_{1}\end{array}$ & $\begin{array}{c}2,52 \pm 0,89 \\
\mathrm{a} \mathrm{B}_{1}\end{array}$ & $\begin{array}{c}7,52 \pm 0,77 \\
\mathrm{a} \mathrm{B}_{2}\end{array}$ & $\begin{array}{c}12,45 \pm 1,83 \\
\mathrm{~b} \mathrm{~A}_{2}\end{array}$ & $\begin{array}{c}0,13 \pm 0,02 \\
\mathrm{a} \mathrm{B}_{3}\end{array}$ & $\begin{array}{c}1,34 \pm 0,43 \\
\mathrm{~b} \mathrm{~A}_{3}\end{array}$ & $\begin{array}{c}0,21 \pm 0,13 \\
\mathrm{a} \mathrm{B}_{4}\end{array}$ & $\begin{array}{c}2,04 \pm 0,73 \\
\mathrm{a} \mathrm{A}_{4}\end{array}$ \\
\hline Maali & $\begin{array}{c}27,38 \pm 3,42 \\
\text { a A }\end{array}$ & $\begin{array}{c}5,50 \pm 1,24 \\
\text { a B }\end{array}$ & $\begin{array}{c}21,57 \pm 5,91 \\
\text { a } A_{1}\end{array}$ & $\begin{array}{c}2,15 \pm 0,66 \\
\mathrm{a} \mathrm{B}_{1}\end{array}$ & $\begin{array}{c}7,69 \pm 0,63 \\
\mathrm{a} \mathrm{B}_{2}\end{array}$ & $\begin{array}{c}14,16 \pm 2,33 \\
\mathrm{a} \mathrm{A}_{2}\end{array}$ & $\begin{array}{c}0,12 \pm 0,02 \\
\mathrm{a} \mathrm{B}_{3}\end{array}$ & $\begin{array}{c}1,70 \pm 0,40 \\
\mathrm{a} \mathrm{A}_{3}\end{array}$ & $\begin{array}{c}0,19 \pm 0,15 \\
\mathrm{a} \mathrm{B}_{4}\end{array}$ & $\begin{array}{c}1,57 \pm 0,56 \\
\mathrm{~b} \mathrm{~A}_{4}\end{array}$ \\
\hline
\end{tabular}


Table 3: Effect of tillage, crop-rotation and genotype on total phenolics content,total flavonoids content and protein content of two durum wheat genotypes grains and straw in Kef during 2014-2015 growing season.

\begin{tabular}{|c|c|c|c|c|c|c|}
\hline \multirow[t]{2}{*}{ Treatment } & \multicolumn{2}{|c|}{$\begin{array}{l}\text { Total phenolics content } \\
\text { (mg GAE/g of DW) }\end{array}$} & \multicolumn{2}{|c|}{$\begin{array}{l}\text { Total flavonoids content } \\
\text { (mg RE/g of DW) }\end{array}$} & \multicolumn{2}{|c|}{$\begin{array}{c}\text { Protein content } \\
(\%)\end{array}$} \\
\hline & GTPC & STPC & GFTC & STFC & GPC & SPC \\
\hline \multicolumn{7}{|l|}{ Tillage } \\
\hline $\mathrm{CT}$ & $4,868 \pm 2,890 a^{1} A^{2}$ & $\begin{array}{c}6,502 \pm 3,640 \\
\text { a A }\end{array}$ & $\begin{array}{c}0,495 \pm 0,147 \\
\text { a B1 }\end{array}$ & $\begin{array}{c}1,010 \pm 0,166 \\
\text { a A1 }\end{array}$ & $\begin{array}{c}16,837 \pm 1,579 \\
\text { a A2 }\end{array}$ & $\begin{array}{c}3,141 \pm 1,008 \\
\text { a B2 }\end{array}$ \\
\hline ChT & $\begin{array}{c}4,850 \pm 4,077 \\
\text { a A }\end{array}$ & $\begin{array}{c}4,531 \pm 2,735 \\
\text { a A }\end{array}$ & $\begin{array}{c}0,495 \pm 0,296 \\
\text { a B1 }\end{array}$ & $\begin{array}{c}1,026 \pm 0,254 \\
\text { a A1 }\end{array}$ & $\begin{array}{c}16,287 \pm 1,977 \\
\text { a A2 }\end{array}$ & $\begin{array}{c}3,011 \pm 0,903 \\
\text { a B2 }\end{array}$ \\
\hline NT & $\begin{array}{c}4,942 \pm 3,186 \\
\text { a A }\end{array}$ & $\begin{array}{c}7,878 \pm 4,510 \\
\text { a A }\end{array}$ & $\begin{array}{c}0,484 \pm 0,106 \\
\text { a B1 }\end{array}$ & $\begin{array}{c}1,031 \pm 0,139 \\
\text { a A1 }\end{array}$ & $\begin{array}{c}15,296 \pm 2,168 \\
\text { b A2 }\end{array}$ & $\begin{array}{c}3,078 \pm 0,797 \\
\text { a B2 }\end{array}$ \\
\hline \multicolumn{7}{|l|}{ Crop-rotation } \\
\hline $2-\mathrm{yr}$ & $\begin{array}{c}4,701 \pm 3,678 \\
\text { a A }\end{array}$ & $\begin{array}{c}5,966 \pm 2,926 \\
\text { a A }\end{array}$ & $\begin{array}{c}0,469 \pm 0,253 \\
\text { a B1 }\end{array}$ & $\begin{array}{c}1,045 \pm 0,238 \\
\text { a A1 }\end{array}$ & $\begin{array}{c}15,641 \pm 2,243 \\
\text { a A2 }\end{array}$ & $\begin{array}{c}2,974 \pm 0,814 \\
\text { a B2 }\end{array}$ \\
\hline $3-y r$ & $\begin{array}{c}5,073 \pm 3,052 \\
\text { a A }\end{array}$ & $\begin{array}{c}6,638 \pm 4,681 \\
\text { a A }\end{array}$ & $\begin{array}{c}0,514 \pm 0,117 \\
\text { a B1' }\end{array}$ & $\begin{array}{c}1,000 \pm 0,123 \\
\text { a A1 }\end{array}$ & $\begin{array}{c}16,639 \pm 1,593 \\
\text { a A2 }\end{array}$ & $\begin{array}{c}3,180 \pm 0,965 \\
\text { a B2 }\end{array}$ \\
\hline \multicolumn{7}{|l|}{ Genotype } \\
\hline Chili & $\begin{array}{c}4,580 \pm 2,787 \\
\text { a A }\end{array}$ & $\begin{array}{c}6,163 \pm 3,557 \\
\text { a A }\end{array}$ & $\begin{array}{c}0,500 \pm 0,168 \\
\text { a B1 }\end{array}$ & $\begin{array}{c}1,042 \pm 0,168 \\
\text { a A1 }\end{array}$ & $\begin{array}{c}16,672 \pm 1,922 \\
\text { a A2 }\end{array}$ & $\begin{array}{c}3,150 \pm 0,848 \\
\text { a B2 }\end{array}$ \\
\hline Maali & $\begin{array}{c}5,193 \pm 3,867 \\
\text { a A }\end{array}$ & $\begin{array}{c}6,440 \pm 4,245 \\
\text { a A }\end{array}$ & $\begin{array}{c}0,483 \pm 0,224 \\
\text { a B1 }\end{array}$ & $\begin{array}{c}1,003 \pm 0,209 \\
\text { a A1 }\end{array}$ & $\begin{array}{c}15,608 \pm 1,951 \\
\mathrm{a} \mathrm{A} 2\end{array}$ & $\begin{array}{c}3,004 \pm 0,941 \\
\text { a B2 }\end{array}$ \\
\hline
\end{tabular}

${ }^{1}$ In each column, values not followed by the same minuscule letters for the same treatment are significantly different $(p<0.05)$.

${ }^{2}$ In each line, values of the same mineral element not followed by the same majuscule letters for the same parameter are significantly different $(p=0.05)$.

${ }^{*} 2$-yr, two year crop-rotation; 3-yr, three year crop-rotation; ChT, chisel tillage; CT, conventional tillage; GPC, grain protein content; GTFC, grain total flavonoids content; GTPC, grain total phenolics content; NT, no tillage; SPC, straw protein content; STFC, straw flavonoids content; STPC, straw phenolics content; TKW, thousand of kernel weight. 
4.4 Total phenolic content (TPC) and Total flavonoid content (TFC): Analysis of variance of TPC and TFC showed that the effects of tillage $(\mathrm{T})$, crop rotation $(\mathrm{R})$ and genotype $(G)$ were not significant (Table 3). There were significant $T \times R$ and $R \times G$ interactions effects on TPC. Straw TFC was significantly higher than grain TFC.

4.5 Parameters relationships: As shown in Table 4, GY showed significant positive correlations with BY and TKW. Even if the correlations were not significant for most of them, GY was negatively correlated to mineral elements concentrations ( $\mathrm{N}, \mathrm{P}, \mathrm{K}, \mathrm{Ca}$ and $\mathrm{Na}$ ) of grain. In addition, some negative correlation coefficients, linking grain yield and grain composition, were noted. Some highly significant negative correlations were recorded between GY and GN, and accordingly GPC. Similarly, TKW presented highly significant negative correlation with GN and GPC, and a significant negative correlation with GP\%. For the straw, positive significant correlation related $\mathrm{K}$ to $\mathrm{Ca}$, when it was negatively correlated to $\mathrm{Na}$. Besides, the correlations between grain and straw parameters indicated positive correlations between SN, GN and consequently SPC and GPC.

Table 4: Correlation coefficients among yield and quality parameters of two durum wheat genotypes in 3 different tillage systems and 2 crop-rotations systems in Kef during 2014-2015 growing season.

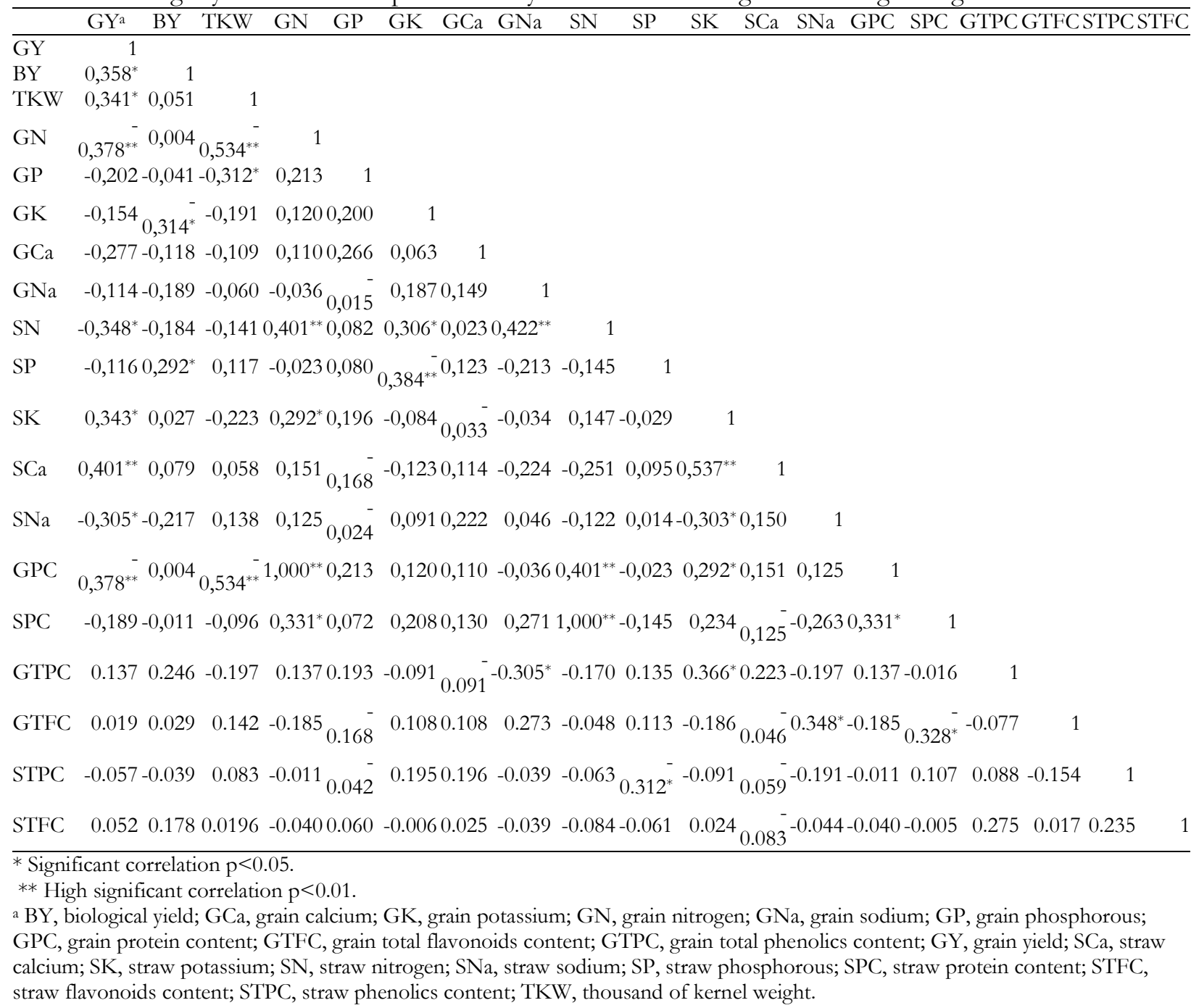




\section{DISCUSSION}

5.1 Effect of Tillage: Crop production in the semi-arid regions is highly dependent on rainfall, and frequent droughts are a limiting factor of yields. In such regions NT, has been suggested as a way of improving water availability in the soil profile, soil organic matter and soil nutrients. In this study, yield parameters did not vary under different tillage methods. These results are similar to those of Montemurro \& Maiorana (2014) who determined the responses of durum wheat to soil tillage and found no significant effect of tillage on grain yield. In similar, Hao et al. (2001) studied the effect of conventional and minimum tillage on crop yield for soft wheat (Triticum aestivum L.) and noted no significant effects on grain yield for three successive cropping seasons. Otherwise, Woźniak et al. (2014) obtained higher durum wheat grain yield under conventional tillage compared to reduced tillage. However, De Vita et al. (2007) studied the effect of tillage on durum wheat yield in two Italian regions for three years and higher yields were observed under NT in dry years compared to CT when this difference was not remarkable in wet years. They concluded that the resultant effects were dependant on the region and the year. In addition, Alvarez and Steinbach (2009) reported that the effect of tillage on yield parameters depends on the crop. In a cool Atlantic climate, the variability of winter wheat grain yield under different tillage system was dependent on the rainfall and temperature of the year (Brennan et al., 2014). Minerals in plants play a major role for the maintenance of certain physicochemical processes, which are essential to life. Regarding macronutrients, nitrogen $(\mathrm{N})$, phosphorus $(\mathrm{P})$, potassium $(\mathrm{K})$ and calcium $(\mathrm{Ca})$ have specific functions in plant. They are components of nucleic acids, proteins, hormones, coenzymes and chlorophylls, phospholipids, adenosine triphosphate (ATP), etc. Our results showed that the effect of tillage on mineral composition of grain and straw is dependent on mineral elements considered. In our case, NT showed the lowest GN. López-Bellido \& López-Bellido
(2001), who found that wheat under NT presented lowest $\mathrm{N}$ uptake compared to CT for three successive cropping seasons, report similar results. As stated by Woźniak et al. (2014), reduced tillage showed higher mineral elements $(\mathrm{P}, \mathrm{K}, \mathrm{Ca})$ concentrations than conventional tillage. In contrary, Ercoli et al. (2017) found that conventional tillage had lower GN concentration than reduced tillage during the transition phase from conventional to reduced tillage. The low values of nitrogen recorded for NT could be explained by the fact that it may alter the availability of plant nutrients and may necessitate reconsidering the fertilizer management. Due to fertilizer management, crop residue and nutrients move shallower into the soil; NT permits the accumulation and concentration of nutrients in the top few inches of soil. Thus, stratification and accumulation of nutrients can limit the crop nutrient availability (Shipitalo et al., 2013). As protein content is directly related to $\mathrm{N}$ concentration, NT showed the lowest GPC. These results are in accordance with those of Šíp et al. (2013) who found that conventional tillage presented higher protein yield in winter wheat compared to reduced tillage. In contrast, Rakszegi et al. (2016) reported that the management system, organic and conventional, had not significant effect on protein content. For grain and straw, no effects of tillage were noted on TPC and TFC. As reported by Stracke et al. (2009) management practices such as conventional and organic practices had no effect on wheat phytochemicals concentrations. As management practices could affect TPC and TFC (Asami et al., 2003), the invariabilities observed between different tillage systems were probably due to the time elapsed time between different tillage practices and sampling.

5.2 Effect of crop rotation: Crop rotation is an encouraged practice due to climate change and erosion risks in semi-arid area. In this study, crop-rotation systems did not show any significant effect on yield parameters, minerals elements composition, PC, TPC and TFC. In another way, neither faba bean nor barley, the 
two preceding crops, had an effect on durum wheat yield and quality parameters. These results are in contrast to those found by LópezBellido \& López-Bellido (2001), Woźniak et al. (2014) and Montemurro \& Maiorana (2014).

In fact, López-Bellido \& López-Bellido (2001), when comparing faba bean and wheat as preceding crops, found that faba bean resulted higher durum wheat grain yield and $\mathrm{N}$ concentration. Similarly, Woźniak et al. (2014) noted that legumes as preceding crop presented the highest durum wheat yield parameters and mineral elements concentration. Montemurro \& Maiorana (2014) found also that legume as preceding crop showed the most important yield parameters and $\mathrm{N}$ concentration.

5.3 Effect of genotype: The two studied genotypes "Chili" and "Maali" differed significantly for GY. Deghaïs et al. (2007) studied some Tunisian durum wheat genotypes and noted lower grain yield for 'Chili'. In parallel, Arduini et al. (2006) found that genotype significantly affected grain yield and yield components in durum wheat. They found that modern genotypes had higher yield than the old ones. Similarly, some genotypes showed significant effects on wheat grain yield (Rozbicki et al., 2015; Studnicki et al., 2016). The obtained results in relation to mineral elements concentration, TPC, TFC and PC showed no significant differences between 'Chili' and 'Maali'. In contrast, Guttieri et al. (2015) found that wheat genotype had a significant effect on mineral elements concentration. Additionally, Taghouti et al. (2010) reported a significant effect of durum wheat genotypes on some quality parameters such as PC. In parallel, Menga et al. (2010) studied some cereal species and noted that genotype had a significant effect on the phenolic content.

\subsection{Effects of $T, R$ and $\mathbf{G}$ interactions}

In this study, most of interactions had no significant effects on the studied parameters. In fact, results did not present any significant effects on yield parameters. On the contrary,
Ercoli et al. (2017) studied the effect of tillage system, preceding crop and year of cultivation on grain yield of durum wheat. The 3-ways of interaction tillage system $\mathrm{x}$ preceding crop $\mathrm{x}$ year of cultivation significantly affected grain yield. The preceding crop effect varied according to the tillage system and the year of cultivation. They noted that in early transition period from conventional to minimum tillage; the effect of tillage on grain yield was dependent on preceding crops. Furthermore, significant effects of $\mathrm{T} \times \mathrm{R}$ and $\mathrm{R} \times \mathrm{G}$ interactions on TPC were noted. These results are in accordance with the outcomes of other experiments, which revealed that genotype, environment and genotype-environment interactions (Beta et al., 2005) and growing conditions ( $\mathrm{Yu}$ et al., 2003) significantly affected wheat TPC. Some other interactions such as T $\times R$ and $R \times G$ that had significantly affected respectively SK and GCa. However, factors interactions did not show any significant effects on PC. In parallel, Rakszegi et al. (2016) reported that the management system, organic and conventional, had not significant effect on protein content. In contrary, Studnicki et al. (2016) affirmed that the genotype, the environment, the crop management and their interactions could influence grain protein content of wheat.

\subsection{Correlation among yield and quality}

parameters: High significant negative correlations were recorded between some yield parameters and protein content. These results are in accordance to those found by Studnicki et al., (2016) who noted significant negative correlations between yield components and GPC $\%$ and other grain quality parameters of spring wheat. The same correlations were noted between GY and GPC\% of winter wheat (Šíp et al., 2013). These negative correlations between GY and GPC\% could be due to the dilution of protein by non-nitrogen compounds in the grain. 


\section{CONCLUSION}

This study provides a contribution about the effect of tillage, crop rotation and genotype on some yield and quality parameters of durum wheat. The results showed that neither the tillage system nor the crop-rotation system had significantly affected the grain yield of two winter durum wheat genotypes. As expected, the modern genotype 'Maali' showed higher grain yield than 'Chili'. NT significantly decreased the grain nitrogen concentration and, the straw potassium and calcium concentrations. Against all odds, total phenolic content did not exhibit any significant

\section{ACKNOWLEDGEMENTS}

This research did not receive any specific grant from funding agencies in the public, commercial, or not-for-profit sectors. We fully

\section{REFERENCES}

Alvarez R. and Steinbach HS: 2009. A review of the effects of tillage systems on some soil physical properties, water content, nitrate availability and crops yield in the Argentine Pampas. Soil and Tillage Research, 104, 1-15.

Arduini I, Masoni A, Ercoli L. and Mariotti M: 2006. Grain yield, and dry matter and nitrogen accumulation and remobilization in durum wheat as affected by variety and seeding rate. European Journal of Agronomy, 25, 309318.

Asami DK, Hong YJ, Barrett DM. and Mitchell AE: 2003. Comparison of the Total Phenolic and Ascorbic Acid Content of Freeze-Dried and Air-Dried Marionberry, Strawberry, and Corn Grown Using Conventional, Organic, and Sustainable Agricultural Practices. Journal of Agricultural and Food Chemistry, 51, 1237-1241.

Bahri H, Annabi M, Cheikh M'Hamed H. and Frija A: 2019. Assessing the long-term impact of conservation agriculture on wheat-based systems in Tunisia using APSIM simulations under a climate variability under different tillage systems and crop-rotation systems. The two winter durum wheat genotypes demonstrated that with the two crop-rotation systems, yields and most of quality parameters under NT and ChT were similar to those under CT. This study expands our knowledge on durum wheat chemistry variation in relation to agricultural system adopted and provides a basis for selecting the adequate crop-rotation system and genotype following the NT adoption in Tunisian semiarid areas.

acknowledge the help of Pr. Messaoud MARS, Dr. Olfa BOUSSADIA and Dr. Faten ZAOUAY for chemical analysis.

change context. Science of the Total Environment, 692, 1223-1233.

Ben-Hammouda M, M'Hedhbi K, Nasr K. and Kammassi M: 2005. Conservation agriculture and direct drilling: Kef area. Proceedings of the 12th Scientific Days on the Results of Agricultural Research (Agriculture de conservation et semis direct: Zone $\mathrm{du}$ Kef. Actes des 12emes Journées Scientifiques sur les Résultats de la Recherche Agricoles). Hammamet-Tunisia, pp 145 155.

Beta T, Nam S, Dexter JE. and Sapirstein HD: 2005. Phenolic content and antioxidant activity of pearled wheat and rollermilled fractions. Cereal Chemistry, 82, 390-393.

Brennan J, Hackett R, McCabe T, Grant J, Fortune RA. and Forristal PD : 2014. The effect of tillage system and residue management on grain yield and nitrogen use efficiency in winter wheat in a cool Atlantic climate. European Journal of Agronomy, 54, 61-69.

Buri RC, von Reding W. and Gavin MH: 2004. Description and characterization of 
wheat aleurone. Cereal Foods World, 49, 274-282.

Chaieb N, González JL, López-Mesas M, Bouslama M. and Valiente M: 2011. Polyphenols content and antioxidant capacity of thirteen faba bean (Vicia faba L.) genotypes cultivated in Tunisia. Food Research International, 44, 970-977.

Deghaïs M, Kouki M, Gharbi MS. and El Felah M: 2007. Cultivated cereal varieties in Tunisia (Les variétés de céréales cultivées en Tunisie) 445 p.

De Vita, P., Di Paolo, E., Fecondo, G., Di Fonzo, N., \& Pisante, M. (2007). Notillage and conventional tillage effects on durum wheat yield, grain quality and soil moisture content in southern Italy. Soil and Tillage Research, 92, 69-78.

Ercoli L, Masoni A, Mariotti M, Pampana S, Pellegrino E. and Arduini I: 2017. Effect of preceding crop on the agronomic and economic performance of durum wheat in the transition from conventional to reduced tillage. European Journal of Agronomy, 82 (Part A), 125-133.

Guttieri MJ, Baenziger PS, Frels K, Carver B, Arnall B. and Waters BM: 2015. Variation for Grain Mineral Concentration in a Diversity Panel of Current and Historical Great Plains Hard Winter Wheat Germplasm. Crop science, 55, 1035-1052.

Hao X, Chang C, Conner RL. and Bergen P: 2001. Effect of minimum tillage and crop sequence on crop yield and quality under irrigation in a southern Alberta clay loam soil. Soil and Tillage Research, 59, 45-55.

Kjeldahl J: 1883. New method for the determination of nitrogen in organic bodies (Neue Methods zur Bestimmung des Stickstoffs in Organischen Korpern). Journal of Analytical Chemistry, 22, 366-382.

Lavado RS, Porcelli CA. and Alvarez R: 2001. Nutrient and heavy metal concentration and distribution in corn, soybean and wheat as affected by different tillage systems in the Argentine Pampas. Soil and Tillage Research, 62, 55-60.

Liu Y, Sui Y, Gu D, Wen X, Chen Y, Li C. and Liao Y : 2013. Effects of conservation tillage on grain filling and hormonal changes in wheat under simulated rainfall conditions. Field Crops Research, 144, 43-51.

López-Bellido RJ. and López-Bellido L: 2001. Efficiency of nitrogen in wheat under Mediterranean conditions: effect of tillage, crop rotation and $\mathrm{N}$ fertilization. Field Crops Research, 71, 31-46.

Menga V, Fares C, Troccoli A, Cattivelli L. and Baiano A: 2010. Effects of genotype, location and baking on the phenolic content and some antioxidant properties of cereal species. International Journal of Food Science and Technology, 45, 7-16.

Montemurro F. and Maiorana M: 2014. Cropping systems, tillage and fertilization strategies for durum wheat performance and soil properties. International Journal of Plant Production, 8(1), 51-76.

Murphy J. and Riley JP: 1962. A modified single solution method for the determination of phosphate in natural waters. Analytica Chimica Acta, 27, 31-36.

Observatoire National de l'Agriculture 2015. www.onagri.tn/uploads/statistiques/an nuaire-stat-2015.pdf

Rakszegi M, Mikó P, Löschenberger F, Hiltbrunner J, Aebi R, Knapp S, Tremmel-Bede K, Megyeri M, Kovás G, Molnár-Láng M, Vida G, Láng L. and Bedó Z : 2016. Comparison of quality parameters of wheat varieties with different breeding origin under organic and low-input conventional conditions. Journal of Cereal Science, 69, 297-305.

Rozbicki J, Ceglińska A, Gozdowski D, Jakubczak M, Cacak-Pietrzak G, Mądry W, Golba J, Piechociński M, Sobczyński G, Studnicki M. and Drzazga T: 2015. Influence of the cultivar, environment and management on the grain yield and 
bread-making quality in winter wheat. Journal of Cereal Science, 61, 126-132.

Shipitalo MJ, Owens LB, Bonta JV. and Edwards WM: 2013. Effect of no-till and extended rotation on nutrient losses in surface runoff. Soil Science Society of America Journal, 77, 1329-1337.

Singleton VL. and Rossi JA: 1965. Colorimetry of total phenolic with phosphormolybbdic-phosphotungstic acid reagent. American Journal of Enology and Viticulture, 16(3), 144-158.

Šíp V, Vavera R, Chrpová J, Kusá H. and Růžek P: 2013. Winter wheat yield and quality related to tillage practice, input level and environmental conditions. Soil and Tillage Research, 132, 77-85.

Stracke BA, Eitel J, Watzl B, Mäder P. and Rüfer CE: 2009. Influence of the Production Method on Phytochemical Concentrations in Whole Wheat (Triticum aestivum L.): A Comparative Study. Journal of Agricultural and Food Chemistry, 57, 10116-10121.

Studnicki M, Wijata M, Sobczyński G, Samborski S, Gozdowski D. and Rozbicki J: 2016. Effect of genotype, environment and crop management on yield and quality traits in spring wheat. Journal of Cereal Science, 72, 30-37.

Taghouti M, Gaboun F, Nsarellah N, Rhrib R, El-Haila M, Kamar M, AbbadAndaloussi F. and Udupa SM: 2010. Genotype x Environment interaction for quality traits in durum wheat cultivars adapted to different environments. African Journal of Biotechnology, 9(21), 3054-3062.

Woźniak A, Makarski B. and Stępniowska A: 2014. Effect of tillage and previous crop on grain yield, grain quality and weed infestation of durum wheat. Romanian Agricultural Research, 31, 130-137.

Yu L, Perret J, Harris M, Wilson J. and Haley S: 2003. Antioxidant properties of bran extracts from "Akron" wheat grown at different locations. Journal of Agricultural and Food Chemistry, 51, 1566-1570.

Zhishen J, Mengchen T. and Jiamming W: 1999. The determination of flavonoid contents in mulberry and their scavenging effects on superoxide radicals. Food Chemistry, 64(4), 555-559. 